\title{
AJOFE E ALCOOMETRIA: AS ESCOLAS DIANTE DAS MUDANÇAS SOCIOCULTURAIS LIGADAS À PRODUÇÃ̃O DE CACHAÇA ARTESANAL NA MICRORREGIÃO DE ABAÍRA, BAHIA, BRASIL
}

\author{
Ajofe and alcoholmetry: the schools facing the \\ sociocultural changes in relation to the production \\ of hand-made cachaça in the microregion of Abaíra, \\ Bahia, Brazil
}

Rosiléia Oliveira de Almeida ${ }^{1}$

\begin{abstract}
Resumo: Neste trabalho, sustentando-nos em concepções teóricas não essencialistas de cultura, buscamos compreender como as escolas da cidade de Abaíra (BA) podem contribuir para a compreensão das tensões da vida comunitária e para o posicionamento crítico dos alunos diante das estratégias locais de identidade construídas em torno da produção de cachaça artesanal. A partir de um estudo socioantropológico das práticas produtivas, buscamos sensibilizar as escolas para que sintonizassem seus currículos com o meio social. Por intermédio da aplicação do conceito de circularidade entre as culturas, evidenciamos que é possível articular os modelos cognitivos da vida cotidiana e da ciência na aprendizagem conceitual, interpretando as técnicas para se verificar se a cachaça está forte: o teste indiciário do ajofe, vinculado à experiência sociocultural local, e a alcoometria, que envolve a aplicação da racionalidade técnico-científica exigida pela nova configuração social.
\end{abstract}

Palavras-chave: Mudança cultural. Saberes cotidianos. Conhecimento científico. Aprendizagem escolar. Cachaça.

\begin{abstract}
In this work, which is based on non essential cultural theoretical conceptions, we try to understand how local schools of the town of Abaíra (BA) can contribute to lessening social tensions and to creating a critical position for the students who face local issues of identity, which have been built around the production of hand-made cachaça. We directed the educative actions in a socioanthropological study which legitimated our purpose of achieving in making school more meaningful, in order to link curricular activities to social activities. Using the concept of circularity among cultural practices and the educational field, we discovered the possibility of using particular cognitive models of our daily lives linked to a rational technical-scientific approach. In local experience, among the multiple techniques adopted to check if the cachaça is strong, there is a special the test of the ajofe, a method that has a profound historical and cultural meaning, and the alcoholmetry, which involves technical-scientific understanding acquired through the new social configurations.
\end{abstract}

Keywords: Cultural changes. Daily knowledge. Scientific knowledge. School learning. Cachaça.

\footnotetext{
${ }^{1}$ Departamento de Educação II, Faculdade de Educação, Universidade Federal da Bahia. Rua do Rouxinol, 104, apto. 701, Edifício Chateau do Imbuí, Bairro Imbuí. Salvador, BA, Brasil. 41.720-052. roalmeida@ufba.br
} 
Almeida, R. O.

\section{Introdução}

A incorporação de inovações tecnológicas ao processo artesanal de produção de cachaça na microrregião de Abaíra, cidade que se autointitula "a capital da cachaça", situada na

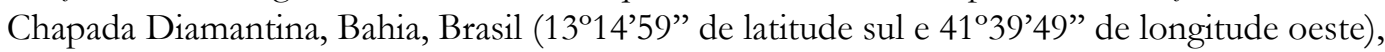
apresenta vários dilemas, já que os obstáculos às mudanças vão muito além das disposições cognitivas situadas no plano das subjetividades, envolvendo injunções práticas dos constrangimentos ambientais, sociais, econômicos e culturais (ALMEIDA, 2008).

Neste trabalho apresentamos resultados de pesquisa de doutorado desenvolvida em cinco escolas, em 2006/2007 (ALMEIDA, 2008), apoiando-nos em um estudo socioantropológico em 12 engenhos ${ }^{2}$, que contribuiu para a compreensão mais profunda dos produtores, como grupamento social e como indivíduos (BRANDÃO, 1995). Buscamos entender como os sujeitos se posicionam diante das estratégias locais de identidade construídas em torno da produção da cachaça comum (Figura 1), as quais contrastam com o cenário intensamente tenso, conflituoso e dinâmico, desde que novos critérios de qualidade do produto passaram a invadir os discursos e as práticas locais (Figura 2), acompanhando o processo sociogenético mais amplo de mudança nos patamares de sensibilidade (ELIAS, 1994).

Figura 1. Escultura de engenho antigo utilizado na produção da cachaça comum, Abaíra, BA.

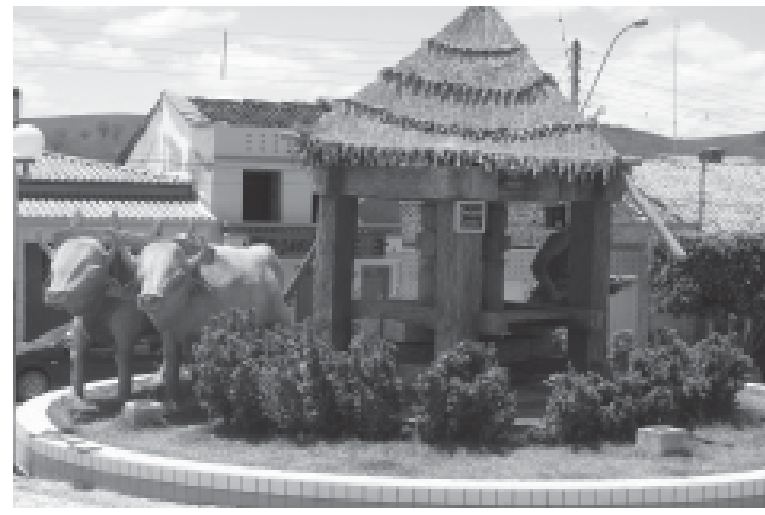

Fonte: Almeida (2008)

\footnotetext{
2 Para Azevedo (2007), as escolas apresentam, como um desafio metodológico, desenvolver ações pedagógicas pertinentes que propiciem a construção de conhecimentos de forma significativa a partir da prática social, o que requer a investigação socioantropológica da experiência viva das culturas e da história das comunidades.
} 
Ajofe e alcoometria: as escolas ...

Figura 2. Escultura da garrafa da cachaça "de qualidade", Abaíra, BA.

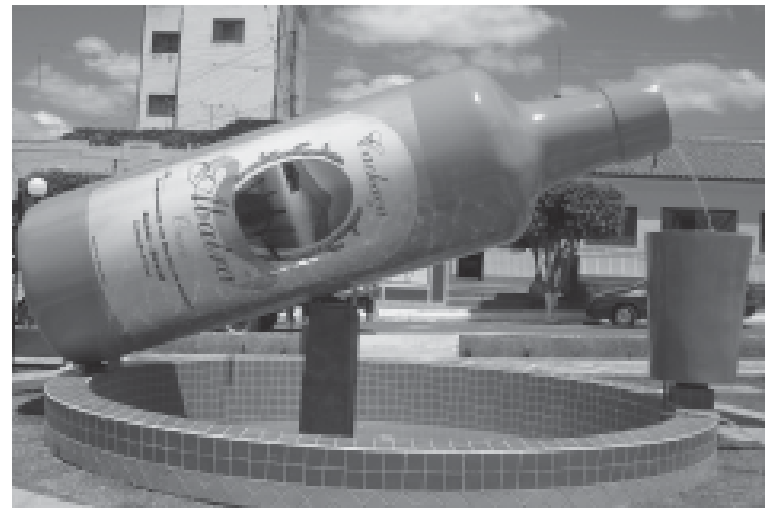

Fonte: Almeida (2008).

Tendo por referência o estudo socioantropológico, analisamos possibilidades de se colocar em relação, em sala de aula, numa perspectiva de circularidade entre as culturas (GINZBURG, 1987; TURA, 2002), as lógicas próprias da ciência e aquelas implícitas nos múltiplos e dinâmicos saberes cotidianos ligados à produção, fornecendo evidências de que a aprendizagem científica e o posicionamento crítico dos alunos em relação às estratégias locais de identidade são favorecidos pela ancoragem sociocultural dos conteúdos.

\section{A perspectiva de circulação de saberes}

A tentativa de sensibilizar os professores para a perspectiva de se colocar em relação, na sala de aula, as lógicas culturais próprias dos saberes cotidianos e científicos foi inspirada por autores influenciados pela psicologia sócio-histórica. Mortimer e Scott (2002) e Candela (1998), a partir da concepção de que a aprendizagem resulta da negociação de significados em torno de diferentes perspectivas culturais, analisam como os recursos culturais dos alunos são mobilizados no plano social da sala de aula, em interações discursivas mediadas pelo professor. Como tínhamos por objetivo evidenciar que as escolas podem articular o plano social da sala de aula com o plano social mais amplo, ajudando os alunos a atribuírem sentido às suas experiências de vida, como indivíduos e como coletividades, nos dedicamos à análise minuciosa dos contextos interativos em sala de aula, optando por tomá-los, no entanto, de forma mais ampla, como evidências da circulação de saberes.

Um equívoco frequente em abordagens metodológicas pautadas pela psicologia cognitivista, em sua busca de respostas para a pergunta "como ensinar melhor?", é que, conforme ressalta Auler (2007), elas mantiveram, em maior ou menor intensidade, o distanciamento da escola em relação ao contexto social mais amplo, através de um enfoque propedêutico dos 
Almeida, R. O.

conteúdos curriculares. Segundo o autor, mesmo em estudos pautados pela psicologia sociointeracionista, observa-se esse distanciamento, pois as análises focam as interações discursivas ocorridas no contexto da sala de aula, sem promover a problematização e a ressignificação da experiência vivida através da abordagem de temas de relevância social ${ }^{3}$.

Nesse sentido, um referencial importante correspondeu ao campo dos estudos culturais, que, segundo Nelson, Treichler e Grossberg (2001, p. 27), envolve a "preocupação com as inter-relações entre domínios culturais supostamente separados", com a mútua determinação entre o conhecimento popular e outras formas discursivas, questionando, em contextos específicos, as práticas culturais, tanto da academia quanto da vida cotidiana, que geram e mantêm a exclusão.

Para compreendermos as possibilidades de se promover a circulação de saberes nas escolas, sustentamo-nos nas discussões em torno do conceito de identidade e de suas implicações educacionais. A teorização cultural contemporânea opõe-se à concepção essencialista, fixa e trans-histórica de identidade, preocupando-se com a convivência dos grupos culturais e dos indivíduos com as mudanças rápidas, abrangentes e contínuas que caracterizam a pósmodernidade, geradas pelas tensões entre o local e o global. Interessa-se, também, pela postura reflexiva gerada por essas mudanças, que tem conduzido ao constante reexame das práticas sociais, promovendo a superação de tipos tradicionais de ordem social e gerando novas posições de identidade - híbridas, plurais, partilhadas, fluidas, estratégicas -, sujeitas ao plano da história (HALL, 2000, 2005; MOREIRA, 2000; SILVA, 2000).

É importante que as escolas não só admitam a existência de diferentes culturas, mas também, conforme enfatiza Azibeiro (2003, p. 87), adotem um enfoque que busque "entender a singularidade e a originalidade de linguagens, valores, símbolos e estilos diferentes de comportamentos que são tecidos pelas pessoas em seu contexto histórico e social peculiar", o que requer considerar as diferenças culturais como construções sócio-históricas e a interculturalidade como a "produção molecular e cotidiana de espaços, de tempos e de subjetividades plurais, movendo-se no terreno do híbrido, do polifônico, do dialógico" (AZIBEIRO, 2003, p. 97).

O conceito de circularidade entre as culturas é empregado, no campo da educação, por Tura (2002), para designar a dinâmica da interação de diferentes padrões e lógicas culturais no espaço escolar. Traduz a concepção de que "a escola é um local privilegiado de troca de ideias, de encontros, de legitimação de práticas sociais, de interação entre gerações, de articulação entre diversos padrões culturais e modelos cognitivos" (TURA, 2002, p. 156), o que se

\footnotetext{
${ }^{3}$ Esse enfoque acaba sendo incoerente com os pressupostos teóricos da abordagem sócio-histórica, pois, conforme Michael Cole e Sylvia Scribner destacam na introdução de A Formação Social da Mente, "para Vygotsky, os estudos antropológicos e sociológicos eram coadjuvantes da observação e experimentação no grande empreendimento de explicar o progresso da consciência e do intelecto humano" (VYGOTSKY, 1989, p. 16). Essa noção é também sustentada por Candela (1998, p. 145), ao afirmar que "a interpretação de um intercâmbio discursivo precisa de um conhecimento do contexto que vai mais além da fala local e de suas referências sequenciais e que requer descrições etnográficas dos conhecimentos culturais, dos antecedentes e dos modelos relevantes dentro dos quais ocorre a ação discursiva". Assim, "não podemos estudar o discurso da sala de aula somente na sua sequencialidade se quisermos reconstruir os significados, mas temos que analisar a trama completa do discurso e tentar fazer inferências sobre as vozes distantes" (CANDELA, 1998, p. 167).
} 
Ajofe e alcoometria: as escolas ...

deve à sua "ação sistemática na aprendizagem de conhecimentos, competências e disposições socialmente reguladas à população de crianças e de jovens de uma específica organização social" (TURA, 2002, p. 156). Essa função articuladora da escola, entre o saber técnico e a relação social que lhe é subjacente, torna-se ainda mais importante no atual cenário, em que, como afirma Certeau (1995), a escola perdeu sua centralidade como distribuidora da ortodoxia em matéria de prática social.

A expressão circularidade entre as culturas é mencionada por Carlo Ginzburg (1987) em seus estudos no campo da história da cultura, para se referir ao intenso influxo recíproco entre a cultura subalterna e a hegemônica, na primeira metade do século XVI, que estaria, segundo ele, traduzido na obra de François Rabelais, analisada por Mikhail Bakhtin no livro A cultura popular na Idade Média e no Renascimento: o contexto de François Rabelais (GINZBURG, 1987).

Ginzburg (1987, p. 20) considera, no entanto, que o "belíssimo livro de Bakhtin” tem um limite: "os protagonistas da cultura popular que ele tentou descrever - camponeses, artesãos - nos falam quase só através das palavras de Rabelais". Assim, tendo em vista as perspectivas de pesquisa histórica indicadas pela obra de Bakhtin e a "escassez de testemunhos sobre o comportamento e as atitudes das classes subalternas do passado" (GINZBURG, 1987, p. 15), o autor buscou realizar, a partir de fontes documentais, um estudo particularizado, sem intermediários, do mundo popular na Idade Média, o qual evidenciou os modos em que se daria esse relacionamento circular, feito de influências recíprocas entre as culturas dominantes e subalternas, a partir da análise do cotidiano e das ideias de um moleiro perseguido pela Inquisição.

Tendo como suposição que não só as formas de pensar e agir ligadas à vida cotidiana de épocas passadas foram silenciadas, mas que o mesmo ocorre na atualidade em relação a grupos sociais cuja experiência cultural contrasta com a racionalidade técnico-científica e com as estratégias de identidade dominantes, é nosso interesse intervir no sentido de contribuir para o desenvolvimento de disposições favoráveis a enfoques educativos que busquem promover a circularidade entre os saberes cotidianos e científicos ligados à produção de cachaça.

Tura (2002, p. 155) considera que "a noção de circularidade entre culturas estabelece, pois, uma mobilidade fundada na inter-relação e na intertextualidade das culturas e subentende movimentos ascendentes e descendentes, que se processam no interior de uma hierarquia de poderes".

No entanto, considerando-se que, nas sociedades atuais, o poder está cada vez mais difuso e as identidades fragmentadas, a ideia de movimentos "de baixo para cima, bem como de cima para baixo", empregada por Ginzburg (1987, p. 13), ao se referir à Europa préindustrial, parece, no atual momento histórico, ter perdido o significado. Canclini (2000), por exemplo, relativiza o paradigma binário subalterno/hegemônico, tradicional/moderno, popular/erudito, ao se contrapor à ideia de que diferentes culturas estejam dispostas em distintos patamares, já que, entre elas, acontecem processos frequentes de hibridações, envolvendo misturas, repulsões, atritos e sínteses.

Nesse sentido, concordando com a concepção de Canen (2002) de que a base do trabalho intercultural crítico é o diálogo, jamais o monólogo que aprisiona os sujeitos exclusivamente em seus modos de ver o mundo, buscamos empreender uma pesquisa nas escolas locais visando promover a sensibilidade à pluralidade cultural e criar disposições para que o 
Almeida, R. O.

currículo escolar incorpore memórias desautorizadas, proibidas, clandestinas ou vergonhosas, situando-as criticamente em relação aos quadros de referência do discurso oficial ${ }^{4}$ e verificando suas contribuições na construção do conhecimento.

A possibilidade de uma educação intercultural exige, segundo Macedo (2004), mais que simplesmente traduzir a diversidade cultural nos currículos escolares. Requer que se busque compreender a relacionabilidade do conhecimento escolar, ou seja, como se estabelecem relações entre as culturas representadas nesse currículo, o que demanda a superação do modelo internalista do currículo, em que se acrescentam e se suprimem conteúdos, sem percebê-lo como espaço de cultura. Conforme ressalta Almeida (2004), a compreensão do conhecimento científico não é condição suficiente para que se compreenda o conhecimento escolar, pois não há uma identidade entre eles. O conhecimento escolar envolve uma seleção cultural de caráter ideológico e arbitrário e passa por mediações didáticas, constituindo-se no embate com outros saberes sociais e deles se distinguindo.

A valorização da produção da cachaça como conteúdo legítimo, em decorrência de seu valor histórico, econômico e cultural, requer que sua abordagem educativa não seja limitada aos espaços informais e não formais de aprendizagem. Assim como a cachaça, que até pouco tempo era restrita aos botecos, aos pobres e aos negros, e só recentemente passou a ser consumida em espaços refinados, a prática cultural da produção da cachaça continuará tendo um caráter marginal se, como afirmam Giroux e Simon (1994), não buscarmos articular o trabalho cultural que se dá em diferentes ambientes educativos, gerando possibilidades de intercompreensão.

Assim, a ênfase em um currículo que valoriza os saberes locais não significa uma visão folclorista, um reducionismo identitário ou uma guetização cultural, conforme são conceituados esses perigos do multiculturalismo em educação, por Canen (2002). A perspectiva de trabalho é o desenvolvimento de situações educativas que busquem superar os estereótipos, a homogeneização das identidades e o encerramento do saber cotidiano nele mesmo, propiciando a aprendizagem científica através da ancoragem social dos conteúdos.

\section{É preciso provar a cachaça para saber se ela está no ponto?}

A pesquisa teve caráter qualitativo, com o nosso envolvimento com os processos culturais do contexto investigado, privilegiando a observação (direta e mediada pelo registro fotográfico e fílmico), a descrição e a interpretação das práticas culturais locais, dos encontros formativos com os professores, durante os quais buscamos atuar no seu nível de disposição para ensaiar modalidades de ensino compromissadas com o contexto sociocultural, bem como das situações didáticas interativas desenvolvidas com os alunos.

Uma reportagem do programa Fantástico, da Rede Globo de Televisão, exibida no dia 2 de abril de 2006, em que a cachaça foi pejorativamente chamada de "isso", e em que se

\footnotetext{
${ }^{4}$ A busca de construção da identidade social de Abaíra como a terra da "cachaça boa", segundo os critérios vigentes na atualidade, faz com que haja um enquadramento da memória pelo discurso oficial, que busca eliminar tudo o que, no passado e no presente, nega essa construção.
} 
denunciava a ocorrência de embriaguez entre crianças em cidades do sudoeste da Bahia, em decorrência do seu envolvimento na prática de se provar a cachaça para ver se está no ponto, teve uma grande repercussão na microrregião de Abaíra. Foi comentada com indignação em todos os povoados, inclusive nas escolas, por transmitir a ideia de que é necessário beber a cachaça para estimar o seu grau alcoólico.

O seguinte trecho da reportagem foi problematizado: "Será que, para produzir cachaça, é necessário prová-la? Será que os produtores daqui de Abaíra provam a cachaça para verificar se ela está no ponto?, gerando a discussão sobre o significado histórico-cultural do teste do ajofe e as tentativas recentes de se substituí-lo pela alcoometria.

- Repórter: Isso é álcool puro. Você bebe isso? (grifo nosso).

- Jovem: Eu provo, tenho que provar para saber se está no ponto.

- Repórter: Quantas vežes você prova isso por dia? (grifo nosso).

- Jovem: Umas cinco vezes. (INFÂNCIA..., 2006)

Como herança do período colonial e em consequência da influência da cultura árabe na Península Ibérica e/ou na África, adota-se, na região, o teste do ajofe (termo derivado de aljôfar - al-ğawhar - que significa pérolas minidas), cuja origem é desconhecida pelos produtores, no qual se estima se a cachaça está forte através de um procedimento indiciário que engloba, de forma complexa, a observação rápida e simultânea do tamanho, quantidade, disposição e tempo de duração das borbulhas formadas pela cachaça ao ser despejada numa cuia (Figura 3). Devido às mudanças na configuração social e ao emprego de práticas de adulteração da cachaça com substâncias espumantes, a adequação dessa técnica tem sido questionada, buscando-se difundir o uso do alcoômetro, que envolve a aplicação da racionalidade técnico-científica (Figura 4).

Figura 3. Teste indiciário do ajofe, Abaíra, BA.

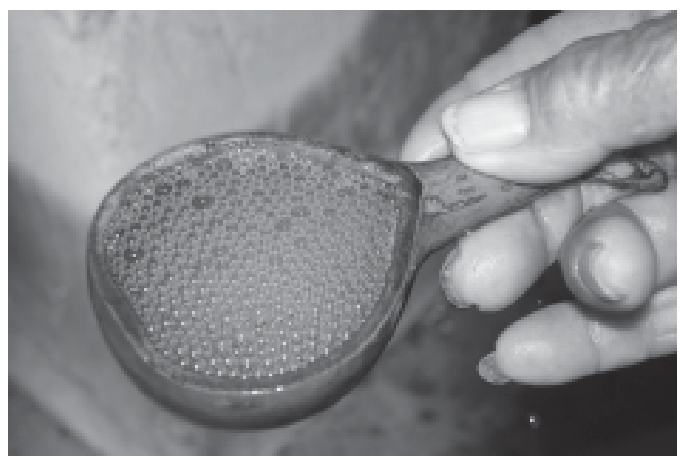

Fonte: Almeida (2008).
Figura 4. Alcoômetro adotado na determinação do grau alcoólico da cachaça, Abaíra, BA.

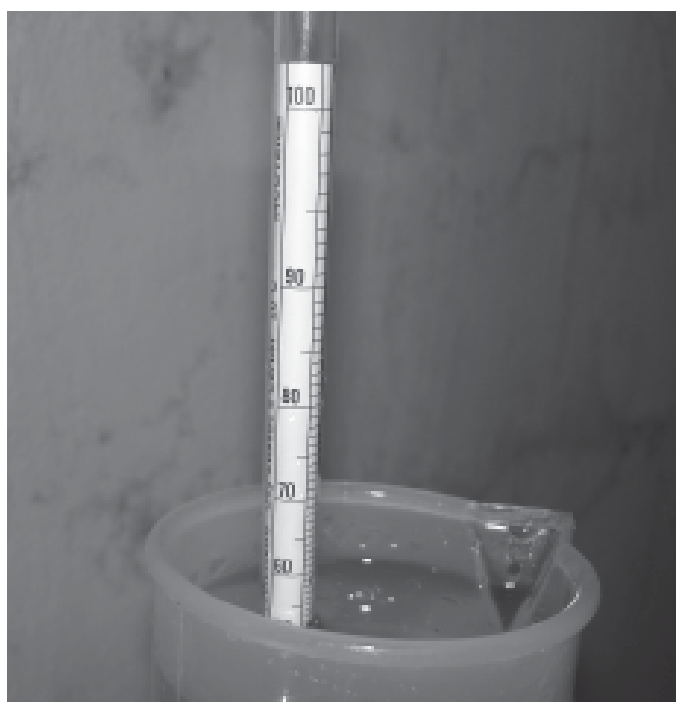

Fonte: Almeida (2008). 
Almeida, R. O.

$\mathrm{Na}$ história da produção do açúcar, à qual a história da produção da cachaça esteve vinculada durante o período colonial, o termo provar era empregado para traduzir o ato de "realizar um experimento, teste ou ensaio destinado à verificação de um fenômeno físico" (FERREIRA, 1999, p. 1656), não se referindo ao "ato de ingerir ou degustar certa porção de comida ou bebida a fim de verificar-lhe a qualidade, o sabor, a temperatura, o teor alcoólico, ou o estado" (FERREIRA, 1999, p. 1656). Almeida (2002) relata várias provas que eram realizadas naquele período: do sopro, do fio, dos aljôfares ${ }^{5}$ etc. A aproximação ao contexto produtivo e as situações didáticas interativas nos permitiram perceber que, como herança cultural, a população de Abaíra emprega os termos provar e experimentar também com essa acepção. Assim, é possível que o diálogo entre o repórter e o jovem tenha envolvido uma dissonância semântica.

"- Essa é uma das formas mais antigas, mas funciona também. Ai se ela ficá aquele colar tá boa... [...] Mas não é muito preciso, mas serve também. Agora hoje com o alcoômetro aí facilita. Mas na maioria das vezes você usa ainda essa técnica de experimentar... eles usam aquelas cuinhas, transferindo de uma pra outra. Mesmo porque, depois dessas falsificações de cachaça... comescaram a usar muito produto pra dá aquele ajofe na cachaça... Por isso que não é mais sinônimo de qualidade da cachaça aquele ajofe." (Wilian, produtor, grifo nosso) ${ }^{6}$

"- A gente experimenta a cachaça fazendo as bolhas... Quando a gente vê que as bolhas já tão pouquinhas, pára de recolher. Aí eles deixam sair mais uns 10 a 15 litros, esse líquido é chamado água fraca. É uma cachaça bem mais fraquinha. Ai, quando vai destilar outra cachaça, coloca novamente no alambique e complementa com a garapa fermentada." (Gabriela, professora, grifo nosso)

"- Mas tem como fazer análise no laboratório, né? Lá [na associação] tem tudo. Lá não se prova nada, é provada através de aparelho. E tem produtores aí que num olhar eles conhecem a cachaça... o tipo de cachaça que é. Quando tem as bolhinhas aí é que a cachaça tá boa." (Cleide, professora, grifo nosso)

\footnotetext{
${ }^{5}$ A constatação do emprego do termo "aljofares" por Miguel Calmon du Pin e Almeida, no livro Ensaio sobre o Fabrico do Açúcar, publicado originalmente em 1834 (ALMEIDA, 2002), foi o ponto de partida para a suspeita de que o termo ajofe, usado localmente, derivava daquela palavra, motivando a pesquisa de sua origem etimológica.

${ }^{6}$ Os sujeitos são identificados por nomes fictícios e seus discursos orais foram mantidos em sua formulação original.
} 
Ajofe e alcoometria: as escolas ...

\section{O teste do ajofe e o conceito de tensão superficial}

Nas diversas escolas, após a discussão do conteúdo veiculado na reportagem e dos significados da palavra "provar", alguns professores e alunos menos familiarizados com o contexto produtivo ficaram em dúvida quanto à ocorrência da prática de se beber a cachaça para estimar o seu grau alcoólico na região, sendo acionadas as experiências de outros alunos na construção de argumentos contrários a essa ideia.

Professora Gabriela: Lá seu pai faz, o quê, Adilson?... Bebe?...

Aluno Adilson: Lá bate a cachaça com cuias de um lado para o outro, se tiver muita bolha tá forte, se tiver pouca tá fraca.

As situações interativas evidenciaram que a maioria dos professores e estudantes conhecia o teste das cuias, relatando casos de parentes e vizinhos que o empregavam, mas não sabia o nome a ele atribuído pelos produtores (teste do ajofe), a origem e a razão desse nome, o princípio físico envolvido (tensão superficial) e a sua importância cultural, sendo uma novidade para eles tomar conhecimento de que o termo é derivado de aljôfar, arabismo cuja origem remonta ao século XIII.

"- Meu tio não separava a cachaça do inicio, mas ele sabia que tinha uma hora que a cachaça não mais prestava, que era cachaça fraca. Agora, como ele sabia, eu não sei! Os produtores falam que quanto mais espuma, melhor a cachaça." (Luiza, professora)

"- O dono do engenho onde eu trabalho ele bate assim... pega uma cuinha, coloca a pinga e bate... é batendo”. (Márcio, estudante)

"- Meu marido diz que quando a cachaça tá forte as bolhas são pequenininhas e demoram um tempinho... Essa técnica das bolhas é válida, não é?" (Gabriela, professora)

Este questionamento da professora Gabriela, que oportunizou a discussão da validade social da técnica, poderia ter sido tomado como situação-problema para o estudo da sua validade científica, ou seja, se há, de fato, uma correlação entre a quantidade de álcool existen-

\footnotetext{
${ }^{7}$ Através de Vargens (2007) tomamos conhecimento, posteriormente, de que esse arabismo, além da variante aljofre, ainda empregada atualmente, que consta nos dicionários, e das variantes locais ajofre/ajofe, apresentou várias variantes arcaicas, remontando o seu uso ao século XIII. Interessado nas variações lexicais, por considerar que elas ajudam a contar a história e as peculiaridades culturais das sociedades, o autor, através de uma abordagem diacrônica, rastreou o uso de vários termos árabes em documentos antigos, constatando as seguintes variantes do termo aljôfar: algofer (século XIV), algofre (1348), aliofar (século XIV), aliofer (século XIV), aliofre (século XIV), alioufar (1388), alíufar (1256), aljoffar (1344), aljoufar (século XIV), aljouffar (1364) e alyofar (século XIV).
} 
Almeida, R. O.

te na cachaça e a quantidade, tamanho, disposição e tempo de duração das bolhas. No entanto, nossa atenção somente se voltou para a abordagem do fundamento físico do fenômeno quando surgiu, em sala de aula, a discussão sobre a influência da temperatura da cachaça no resultado do teste do ajofe ${ }^{8}$.

Roberta: É verdade que quando a cachaça tá quente é mais difícil saber pela espuma se ela tá forte ou se ela tá fraca ou não tem nada a ver?

Amanda: Os caroço fica diferente quando a cachaça tá quente e os produtor custuma esperá isfriá pra fazêe o teste.

A partir do comentário de que as escolas locais precisam valorizar, do ponto de vista sócio-histórico, os conhecimentos cotidianos envolvidos no teste do ajofe e, ao mesmo tempo, propiciar o acesso dos alunos aos conhecimentos científicos e tecnológicos envolvidos no uso dos aparelhos, que se ajustam melhor à conjuntura do mundo atual - no qual foram instituídos mecanismos legais de controle de qualidade da cachaça e mecanismos ilegais de burlar o teste do ajofe com o uso de substâncias espumantes (detergente, mel, ajofina ${ }^{9}$, biscolache etc.) -, os professores e alunos passaram a evidenciar que tinham conhecimento de casos de adulteração da cachaça comum. Assim, foram realizados testes com o emprego de substâncias espumantes, verificando suas características hidrofílicas, dissolvendo-se facilmente na cachaça fraca, e sua propriedade espumante, relacionada à alteração da tensão superficial.

\section{O funcionamento do alcoômetro: conceitos de densidade e empuxo}

A possibilidade de uso do alcoômetro para determinar o grau alcoólico da cachaça era desconhecida pela maioria dos professores. Ao tomarem contato com o alcoômetro, os poucos professores que manifestaram familiaridade com o aparelho forneceram indicações do ajuste não orgânico do processo produtivo à estratégia de identidade local vinculada à cachaça de qualidade.

\footnotetext{
${ }^{8}$ É interessante observar que o teste do ajofe fundamenta-se na tensão superficial da mistura de água e etanol existente na cachaça, pois a tensão superficial da água é superior à do etanol, de forma que os comentários dessas alunas expressam saberes complexos contidos na experiência cotidiana. Como a tensão superficial dessas substâncias varia em função da temperatura, quando a cachaça está quente haverá alteração nos vários e sutis indícios observados pelos produtores, prejudicando a realização do teste. Assim como o estudo da densidade e do empuxo ajudou os alunos a compreenderem o funcionamento do sacarímetro e do alcoômetro (artefatos da racionalidade técnico-científica), o estudo da tensão superficial poderia também ajudá-los a entender o fundamento do teste do ajofe e os fatores que o influenciam, percebidos intuitivamente na vida cotidiana. Infelizmente, no momento em que a aluna fez este comentário não nos demos conta de que poderíamos ter proposto a investigação empírica do fenômeno e a busca de explicações para o mesmo, favorecendo, ainda mais, a circulação entre os saberes cotidianos e científicos.

${ }^{9} \mathrm{O}$ termo ajofina, de uso local, designa uma substância que provoca bolhas na cachaça, sendo derivada do termo ajofe, o que evidencia a criatividade da linguagem cotidiana.
} 
Ajofe e alcoometria: as escolas ...

"- Tem vários aparelhos de medição... tem o alcoômetro, tem o sacarímetro. Mede em graus Gay-Lussac... e tem o grau Cartier também. O meu pai também tem... tem não!... tinha! Porque acho que o dele já quebrou... Men pai já deve ter quebrado! Meu pai... sei lá! É porque ele é daquele tipo que... é a organização mesmo!" (Henrique, professor)

Os professores desconheciam que o alcoômetro tinha, como princípios físicos de funcionamento, a densidade e o empuxo, sendo desafiados a levantar hipóteses e a elaborar explicações. Também não sabiam que era necessário fazer a correção do valor lido quando a temperatura da cachaça estivesse diferente de $20^{\circ} \mathrm{C}$. Todos manifestaram surpresa ao tomarem conhecimento de que os densímetros, vistos por eles como uma inovação, eram muito antigos, sendo usados na produção de açúcar desde o Brasil Colônia.

Ao compararem o alcoômetro e o sacarímetro, os professores anteciparam que ambos marcariam o zero ao serem colocados na água, pois ela não tinha nem açúcar e nem álcool. Quando colocaram os aparelhos na água, manifestaram surpresa com sua disposição diferente:

"- O sacarimetro descen e o alcoômetro subiu! Por quê??" (Selma, professora)

Consultando as escalas, alguns professores predisseram corretamente que "se tivesse álcool o alcoômetro iria descer e se tivesse açúcar o sacarímetro iria subir".

Os professores confirmaram que o sacarímetro flutuava mais quanto mais doce a garapa, e o alcoômetro afundava mais quanto mais forte a cachaça, sendo que, com base nessas observações, apenas a professora Luíza chegou à conclusão sobre a diferença de densidade entre as três substâncias.

"- Então, o álcool é menos denso que a água e a garapa é mais densa que a água, é? Por isso que a escala é invertida?" (Luíza, professora)

Com base na explicação da diferença de densidade entre o caldo da cana (maior que $\left.1 \mathrm{~g} / \mathrm{cm}^{3}\right)$, água $\left(1 \mathrm{~g} / \mathrm{cm}^{3}\right)$ e álcool $\left(0,789 \mathrm{~g} / \mathrm{cm}^{3}\right)$, os professores chegaram à conclusão de que, se tivessem o mesmo volume de caldo de cana, água, cachaça e álcool, as massas seriam diferentes. Entusiasmados com a constatação de que a densidade da garapa e da cachaça podia variar e que esse fato estava sendo tomado como base explicativa do funcionamento dos aparelhos, os professores comentaram:

Luíza: No livro tem exemplo de densidade com o gelo e a água, por que o gelo flutua na água mesmo sendo de água..., engraçado!... mas aprender densidade ligando à realidade adquire um outro significado.

Cleide: Ligar à realidade fica até mais interessante.

Através da comparação sensorial das massas de quatro garrafas de $500 \mathrm{~mL}$, cheias dos quatro produtos, garapa, água, cachaça e álcool, os professores confirmaram a diferença de densidade das substâncias: 
Almeida, R. O.

Selma: É enorme a diferença da água para o álcool!

Luíza: Dá pra perceber que a cachaça fica no meio.

Cleide: A garapa pesa mais... tem diferença mesmo. ${ }^{10}$

Utilizando uma balança de cozinha, os professores confirmaram essas conclusões. Ficaram intrigados por não compreenderem por que a densidade interfere na disposição dos aparelhos, sendo introduzido o conceito de empuxo, com o esclarecimento de que, quanto mais doce a garapa, maior sua densidade e mais força o líquido exerce para cima, empurrando o sacarímetro. No caso da cachaça, quanto mais álcool, menor a densidade e menos força o líquido exerce para cima, de forma que o alcoômetro afunda mais.

Para os professores, foi uma novidade saber que a densidade das substâncias varia em função da temperatura, razão pela qual o sacarímetro e o alcoômetro são calibrados para medições à temperatura de $20^{\circ} \mathrm{C}$. Assim, o valor aferido, caso a temperatura do líquido seja diferente de $20^{\circ} \mathrm{C}$, é aparente, sendo necessário realizar a correção com o uso concomitante de um termômetro e de quadros de correção. Os professores perceberam que a compreensão, pelos alunos, da razão de se precisar adicionar ou subtrair algum valor ao lido nos aparelhos iria requerer o estudo da variação da densidade dos líquidos em função da temperatura. Ao ouvir nosso comentário de que uma evidência dessa variação era bastante familiar aos alunos, a temperatura da água do condensador, a professora Cleide deu sentido à atitude dos alunos observada na visita que realizamos a um engenho.

"- Na caixa do condensador a água fica quente... bem quente. Conforme você vai abaixando a mão fica frio. Eé engraçado que os alunos prestaram atenção... a gente foi chegando no alambique e a primeira coisa que fizeram: correram tudo pra caixa e foram tudo enfiando as mãozinhas! Eu fiquei observando e perguntando por que eles estavam fazendo aquilo!... Um deles me chamou: "Tia, vem aqui pra você ver um negócio". Ai fui. Ele me explicou: "Aqui tá quente e a gente vai afundando e vai ficando frio". E tava quente mesmo... bem quente assim! E conforme você ia abaixando a mão a temperatura ia abaixando!" (Cleide, professora)

Discutimos outras evidências cotidianas percebidas pelos próprios alunos que poderiam ser acionadas para favorecer o entendimento da variação da densidade em função da temperatura, como a percepção de que a água no fundo do rio é mais fria que a da superfície e, também, a reação de assombro de uma aluna que realiza a vistoria sensorial da limpeza da cachaça de qualidade ao constatar que, perto do dispositivo de iluminação, o líquido aumenta de volume. Como evidência experimental, os professores constataram que garrafas de $500 \mathrm{~mL}$ com volumes iguais de cachaça quente e fria tinham massas diferentes: $498 \mathrm{~g}$ e $502 \mathrm{~g}$, respectivamente.

\footnotetext{
${ }^{10}$ Inicialmente foi feita a comparação das massas de três substâncias: água, álcool e cachaça. A massa da garapa passou a ser também aferida e comparada por sugestão da aluna Amanda, conforme relatamos na seção "As três garrafas e o conceito de densidade".
} 
Ajofe e alcoometria: as escolas ...

Os professores, após efetuarem medidas e correções com várias amostras de garapa e cachaça a diferentes temperaturas, compreenderam que: a) na garapa quente, menos densa, $\mathrm{O}$ aparelho afunda mais do que quando a garapa está a $20^{\circ} \mathrm{C}$, indicando um valor aparente do teor de açúcares menor do que o valor real, sendo necessário adicionar o valor encontrado no quadro; b) na cachaça quente, também menos densa, o aparelho também afunda mais do que quando a cachaça está a $20^{\circ} \mathrm{C}$, indicando um valor aparente do grau alcoólico maior do que o valor real, sendo necessário subtrair o valor encontrado no quadro.

$$
\begin{aligned}
& \text { "- A garapa é mais densa que a água e a cachaça é menos densa que a água, por } \\
& \text { isso as escalas dos aparelhos são invertidas e em um caso tem que somar e no outro } \\
& \text { tem que subtrair. Em temperatura abaixo de } 20{ }^{\circ} \mathrm{C} \text { já é o contrário, na garapa } \\
& \text { tem que subtrair e na cachaça tem que somar!” (Luíza, professora) }
\end{aligned}
$$

Os professores reconheceram a necessidade de os alunos perceberem que muitos produtores são enganados pelos compradores, já que estes detêm o controle da relação comercial, utilizando o alcoômetro e pagando apenas dez centavos a mais por cada grau de álcool a mais na cachaça. Mesmo considerando que poderia haver dificuldades de entendimento dos conceitos, estavam confiantes de que a experiência cotidiana dos alunos nos engenhos iria favorecer a aprendizagem.

$$
\begin{aligned}
& \text { "- Nós não tínhamos esse conhecimento! Como que a gente ia trabalhar!? Agora } \\
& \text { nós estamos aprendendo. Você está ensinando pra gente e nos ensinando como } \\
& \text { ensinar pra eles, valorizando o conhecimento cotidiano. É um processo ótimo pra } \\
& \text { gente. Os alunos disseram "Nós gostamos tanto daquela aula! Vai continuar?”. } \\
& \text { Acho que é porque eles gostam de experiências e também porque eles questionam e } \\
& \text { passam a dar sentido a práticas do dia-a-dia." (Selma, professora) }
\end{aligned}
$$

Poucos alunos conheciam o alcoômetro e o associaram à produção da cachaça de qualidade. Flávio explicou: "põe na cachaça e ele mede os graus". Após a explicação de que o valor lido no aparelho tem um significado, referindo-se ao percentual de álcool existente na cachaça, todos logo reconheceram a importância de seu uso, mesmo pelos produtores da cachaça comum, já que o preço do produto é definido pelos atravessadores de acordo com o grau alcoólico, que geralmente é medido só por eles. Fábio comentou: "então, tanto quem compra quanto quem vende a cachaça comum deve ter o aparelho pra podê testá e não tê prejuízo, né?".

Constatamos que os alunos não sabiam distinguir cachaça e aguardente, reproduzindo a sinonímia empregada na vida cotidiana. Também desconheciam a existência de uma lei que determina a quantidade mínima e máxima de álcool na cachaça e na aguardente. A partir da análise da descrição desses produtos na Instrução Normativa no 13 (BRASIL, 2005), que fixa os padrões de identidade e qualidade desses produtos, os alunos concluíram que a maior parte da cachaça comum produzida na microrregião de Abaíra não é, de fato, cachaça, por não estar na faixa de 38 a $48^{\circ} \mathrm{G} . \mathrm{L}$.

Os alunos perceberam rapidamente a diferença na escala (variação de 0 a $100{ }^{\circ} \mathrm{G}$.L.) e sua inversão em relação ao sacarímetro, com o zero disposto na parte inferior, inferindo que, se o aparelho fosse colocado na água, iria flutuar muito [e não afundar muito como o sacarí- 
Almeida, R. O.

metro!] e marcar $0{ }^{\circ}$ G.L., e, se fosse colocado no álcool, iria afundar muito e marcar $100{ }^{\circ} \mathrm{G}$.L Quando questionados sobre qual seria a disposição do aparelho ao ser colocado na cachaça, vários alunos inferiram o resultado: "como a cachaça tem uma mistura de água e álcool, então dá no meio", "vai afundar mais que na água e menos que no álcool", "vai afundar mais ou menos", "vai dar perto do meio", "vai parar no meio". (Figuras 5 a 7). Os alunos não conseguiram explicar a razão da inversão da escala, mas um deles percebeu logo, intuitivamente, que cada aparelho era projetado de acordo com as características específicas de cada líquido, dizendo:

“- E se eu colocar o alcoômetro na garapa?... então, não vai dar certo!” (Hemerson, aluno)

Figura 5. Observação do alcoômetro na água.

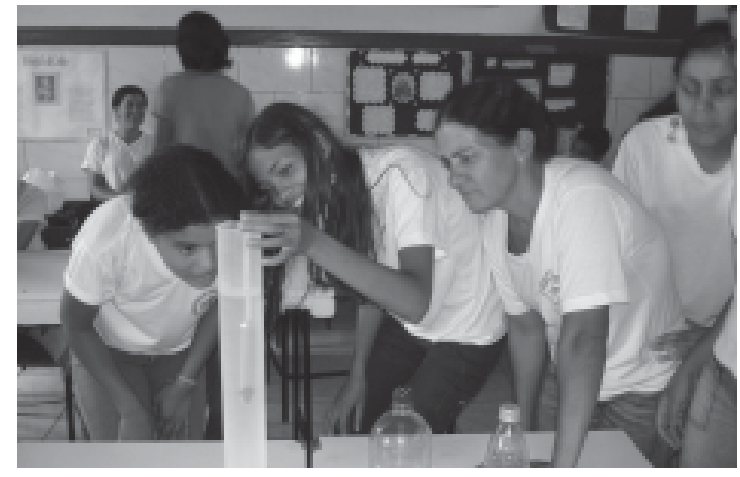

Fonte: Almeida (2008)

Figura 6. Observação do alcoômetro na cachaça.

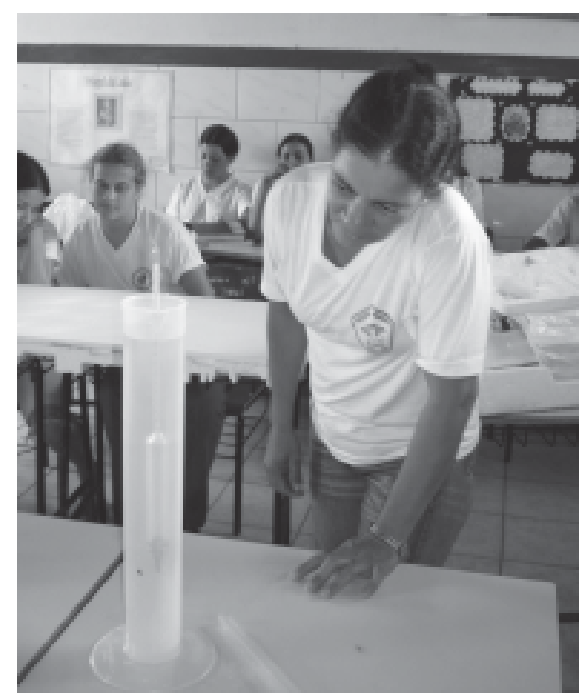

Fonte: Almeida (2008).
Figura 7. Observação do alcoômetro no álcool.

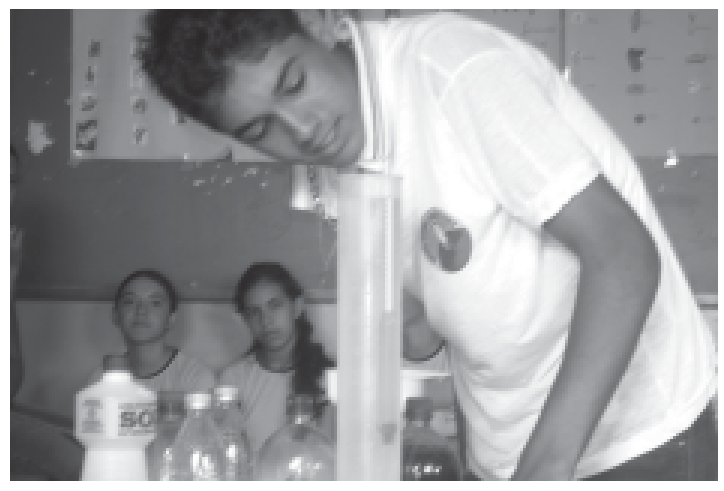

Fonte: Almeida (2008). 
Ajofe e alcoometria: as escolas ...

Os alunos se surpreenderam quando colocaram o alcoômetro no álcool e constataram que marcou $96^{\circ}$ G.L., valor diferente do previsto, $100^{\circ}$ G.L., levantando logo a hipótese de que não era álcool puro: "tem água misturada aí!", "o álcool deve estar misturado com água!", "deve ter um pouquinho de água ai dentro!", "não é álcool puro... tem água!", o que foi confirmado pela consulta ao rótulo.

Em todas as turmas, foi realizada a aferição, pelos alunos, do grau alcoólico de amostras de cachaça de vários produtores, com a determinação do percentual de água e álcool, e a extrapolação do resultado para outros volumes, sendo que tanto os alunos da $5^{a}$ e $6^{a}$ séries quanto os mais avançados na escolaridade desconheciam como efetuar a "regra de três". Vários alunos estimaram corretamente o grau alcoólico da cachaça por meio da observação das bolhas formadas ao se agitar a garrafa, fazendo correlações com o teste do ajofe, e também pelo cheiro.

Os alunos manifestaram ter entendido que o aparelho permite a medida do grau alcoólico, por "flutuar mais ou flutuar menos no líquido", mas não souberam explicar o princípio físico em que se baseia seu funcionamento. Jardiel explicou: "Quanto mais forte a cachaşa, mais ela puxa o alcoômetro pra baixo, é assim?". Apenas Ivan afirmou que o aparelho "ia descer" mais, quanto mais álcool houvesse na cachaça, "por causa da força". Esclareceu, ao ser questionado, que a disposição do aparelho era determinada pela "força do líquido", fazendo um gesto com as mãos para cima. Essa interpretação aproxima-se da lógica científica de explicação do fenômeno, traduzida nos conceitos de densidade e empuxo, sendo esclarecido que, quanto mais "aguada", mais a cachaça empurra o alcoômetro para cima.

Os alunos reconheceram a necessidade de os produtores aprenderem a utilizar os aparelhos, sendo que vários se ofereceram para retornar aos engenhos dos produtores para lhes ensinar. Manifestando disposição para aprender, buscaram esclarecer suas dúvidas: "se colocar pouca cachaça atrapalha o funcionamento do aparelho?", "pode usar o aparelho direto no camburão?". Essa discussão ajudou a criar disposições para a aprendizagem dos princípios físicos envolvidos no funcionamento dos aparelhos.

\section{As três garrafas e o conceito de densidade}

A abordagem dos princípios físicos envolvidos no funcionamento dos aparelhos iniciou-se com a comparação da massa de três garrafas iguais, contendo o mesmo volume de água, cachaça e álcool, primeiro sensorialmente e, depois, com o uso de uma balança de cozinha, o que permitiu que os alunos entendessem o conceito de densidade, relacionando-o com a força que o líquido exerce de baixo para cima sobre os aparelhos, o empuxo. Os alunos do Ensino Fundamental acharam que o álcool ou a cachaça teriam maior massa, mas não souberam apresentar argumentos favoráveis a essa concepção:

Pesquisadora-professora: O volume das substancias nessas garrafas é o mesmo? Vários alunos: Sim!

Pesquisadora-professora: E quando eu colocar essas garrafas na balança, vocês acham que a massa, a quantidade de matéria, que existe nessas garrafas é a mesma? Vários alunos: Não.

Pesquisadora-professora: Qual teria a massa maior? 
Almeida, R. O.

Alguns alunos: $O$ álcool.

Fábio: Eu acho que é a cachaça.

Vários alunos, seguindo a opinião de Fábio: É a cachaça!

Pesquisadora-professora: Por que vocês acham que é a cachaça?

Fábio: Porque a cachaça tem água misturada.

Pesquisadora-professora: Mas se a água faz a cachaça ter maior massa que o

álcool, então a garrafa só com água vai ter maior massa, não?

Fábio: Não sei explicar não.

Luiz Cláudio, rindo: Eu acho que o álcool tem mais massa que os outros dois, mas também não sei explicar não.

Quando compararam a massa das garrafas sensorialmente, os alunos manifestaram grande surpresa com a diferença: "é a água!”; "a água pesa mais!, "a água, é mesmo!”, "então, quer dizer que a água é mais densa que o álcool!", "quanto mais água na cachaça a densidade é maior e ai o aparelho vai subir". Constataram, com o uso da balança, as massas das três garrafas de $500 \mathrm{~mL}$ : água - 550 g; cachaça - 500 g; álcool - 450 g, o que levou o aluno Luiz Cláudio a falar surpreso: "o álcool deu menor e eu falei que o álcool era maior!'. O valor intermediário da cachaça foi relacionado à flutuação do aparelho em $44^{\circ} \mathrm{G}$.L., o que significa que ela continha $44 \%$ do volume em álcool e $56 \%$ do volume em água.

Após os alunos terem entendido que as três garrafas, apesar de possuírem o mesmo volume, tinham massas diferentes, sistematizamos o conceito de densidade, sendo que o seguinte episódio evidenciou o seu entendimento pelos alunos:

Pesquisadora-professora: $O$ que observamos tem relação, então, com a densidade. E o que é a densidade?

Márcio: A água é mais densa.

Pesquisadora-professora: O que significa dižer que a água é mais densa?

Márcio: É que ela tem mais força pra empurrar o objeto pra cima.

Pesquisadora-professora: A água é mais densa. Por ser mais densa ela vai empurrar mais o aparelho para cima do que o álcool. Vejam, a densidade é uma relação entre a massa e o volume de uma substância, e é calculada por uma fórmula: $d=m / V$. A densidade da água é 1 , isso significa que se tivermos $1 \mathrm{~g}$ de água, essa massa de água vai ocupar $1 \mathrm{~cm}^{3}$, ou seja, a densidade da água é $1 \mathrm{~g} / \mathrm{cm}^{3}$. A densidade do álcool também é 1 ?

Alunos: Não!

Pesquisadora-professora: Vocês acham que em $1 \mathrm{~cm}^{3}$ vai caber $1 \mathrm{~g}$, mais de 1 $\mathrm{g}$ ou menos de $1 \mathrm{~g}$ de álcool?

Vários alunos: Menos de $1 \mathrm{~g}$.

Pesquisadora-professora: Isso mesmo, vai caber menos de $1 \mathrm{~g}$ porque o álcool é menos denso que a água. Em $1 \mathrm{~cm}^{3}$ vai caber $0,789 \mathrm{~g}$ de álcool, ou seja, menos de $1 \mathrm{~g}$. Como $1 \mathrm{~cm}^{3}$ corresponde a $1 \mathrm{~mL}$, isso quer dizer que $1 \mathrm{~L}$ de água tem a massa de $1 \mathrm{~kg}$, enquanto que $1 \mathrm{~L}$ de álcool tem a massa de $789 \mathrm{~g}$.

Ian: Aqui no livro tem a densidade do álcool. Diz que é 0,8.

Pesquisadora-professora: Isso. O valor foi arredondado. 
Ajofe e alcoometria: as escolas ...

Entre os alunos do Ensino Médio, não se constatou uma influência significativa da aprendizagem escolar na predição das massas das garrafas. Embora a aluna Milena tivesse empregado o termo densidade para explicar por que a posição do alcoômetro no líquido varia de acordo com a quantidade de álcool na cachaça, questionando "por causa da densidade do liquido?", e todos tivessem conseguido identificar objetos mais ou menos densos que a água, não souberam conceituar densidade. Também tiveram dificuldade de correlacionar a densidade do líquido com a força exercida por ele para cima.

Pesquisadora-professora: Entre a água e o álcool qual é mais denso?

Vários alunos: $O$ álcool.

Pesquisadora-professora: Por que vocês acham que o álcool é mais denso?

Aline: Porque o aparelho afunda mais no álcool.

Pesquisadora-professora: No caso do sacarimetro, se en colocá-lo dentro de um melado, será que ele afunda muito ou pouco?

Vários alunos: Pouco.

Pesquisadora-professora: Isso, pouco, porque, quanto mais denso o líquido, mais ele vai empurrar o aparelho para cima. Quanto mais açucar tem na garapa, mais densa ela fica e mais ela empurra o aparelho para cima, dando um Brix mais alto. No caso do alcoômetro, quanto mais água tem na mistura mais o aparelho flutua. Isso quer dizer que o álcool é mais ou menos denso que a água?

Vários alunos: Menos denso!

Pesquisadora-professora: Isso, quanto mais água tem na mistura, mais densa ela fica e mais o aparelho flutua. Então, dessas três garrafas qual terá maior massa?

Vários alunos: $A$ de água.

Pesquisadora-professora: E a garrafa de cachaça, como será a massa dela se compararmos com as outras duas garrafas?

Vanessa: Mais pesada.

Pesquisadora-professora: Mais pesada que as duas?

Alan: Não. Mais pesada que o álcool e menos que a água.

O aluno Erivaldo manifestou entendimento do conceito de densidade, ao explicar: " $e$ a relação entre a massa e o volume", e predizer que "nas garrafas o volume é o mesmo, mas a massa varia. A garrafa com água pesa mais, porque um litro de água pesa mais que um litro de álcool", convencendo seus colegas dessa ideia, mesmo com a discordância de Jassimar, que afirmou contundente: "um litro de água não pesa mais que um litro de álcool. Se é um litro, é um litro!".

A falta de clareza na compreensão do conceito de densidade evidenciou-se quando os alunos fizeram suas predições em relação à disposição da água, do óleo e do álcool em um frasco: "o óleo é mais denso que a água e fica por cima", mudando de opinião quando o professor Henrique esclareceu que o mais denso afunda: "então, o óleo é menos denso". Em relação ao álcool, apesar das divergências iniciais, chegaram a um consenso de que "o álcool e a água vão ficar por baixo do óleo", concluindo, após o experimento, que o álcool era menos denso que a água e que tínhamos colocado o óleo no meio para que pudessem chegar a essa conclusão "porque a água e o álcool se misturam". A aluna Simone chegou à conclusão de que "a cachaça fraca tem muito água 
Almeida, R. O.

e vai ser mais densa", ideia que foi tomada como referência para explicar o conceito de densidade, através da fórmula e de exemplos, e sua relação com o empuxo exercido por diferentes misturas hidroalcoólicas sobre o aparelho.

A divergência em relação a $1 \mathrm{~L}$ de água e $1 \mathrm{~L}$ de álcool ter ou não a mesma massa foi finalmente esclarecida quando os alunos, ao manipularem as garrafas, chegaram à conclusão de que "a água é mesmo mais pesada", "a densidade da água é mais!". A aluna Amanda fez um comentário que revelou sua capacidade de estabelecer relações e sua compreensão da relação entre a flutuação dos aparelhos e a densidade: "se tivesse uma garrafinha com a garapa dava muito mais, né?... porque o aparelho flutua mais na garapa do que na água". E não é que nem tínhamos pensado nessa possibilidade de também medir a massa da garapa?! ${ }^{11}$ Henrique, que havia vivenciado essa atividade com seus colegas professores, exclamou: "e a gente nem pensou nisso!... uma garrafinha com garapa!... não é que é mesmo!".

Valorizando o raciocínio da aluna, após relembrarmos a fórmula de cálculo da densidade e a correspondência entre as unidades $\mathrm{mL} \mathrm{e} \mathrm{cm}^{3}$, fizemos a seguinte comparação: enquanto $1.000 \mathrm{~mL}$ de água têm a massa de $1.000 \mathrm{~g}$, o que corresponde a uma densidade de $1 \mathrm{~g} /$ $\mathrm{mL}$ (ou $1 \mathrm{~g} / \mathrm{cm}^{3}$ ), $1.000 \mathrm{~mL}$ de álcool têm uma massa menor, $789 \mathrm{~g}$, o que resulta numa densidade menor que a da água: $0,789 \mathrm{~g} / \mathrm{mL}$. Já $1.000 \mathrm{~mL}$ de garapa a $25^{\circ} \mathrm{Bx}$ têm a massa de $1.105 \mathrm{~g}$, o que significa uma densidade maior que a da água, no valor de $1,105 \mathrm{~g} / \mathrm{mL}^{12}$. Ao final da aula, os professores comentaram:

"- No livro de Ciências não trabalha nenbum conceito de Física assim... Agora, que aulas assim, práticas, em que se está manipulando e mostrando, ajuda muito mais do que esse negócio teórico: "o que é densidade?... é a relação massa-volume". (Henrique, professor)

"- Você coloca lá e o aluno só fica fazendo conta. Mas não usa nada... princípio de Arquimedes... e eles não entendem e não prestam atenção... Aqui a gente só tá com livro... livro..." (Evanilson, professor)

O entendimento pelos alunos do princípio físico de funcionamento do aparelho foi confirmado durante o seguinte episódio:

Pesquisadora-professora: Se tiver água na proveta, o que acontece com o alcoômetro? Vai afundar ou flutuar muito?

Amanda, seguida por vários alunos: Vai flutuar... por causa da densidade da água, que é maior.

\footnotetext{
${ }^{11}$ Essa intervenção da aluna Amanda fez com que passássemos a levar também, para a sala de aula, uma garrafa com garapa, para compararmos a massa da garapa e da água e, assim, favorecer o entendimento do funcionamento do sacarímetro e do conceito de densidade.

${ }^{12}$ Nesse momento não fizemos referência à influência da temperatura na densidade das substâncias, pois pretendíamos apresentar posteriormente esse tema como uma situação-problema, para que os alunos entendessem a necessidade de consulta aos quadros de correção, ao se utilizar o sacarímetro e o alcoômetro.
} 
Ajofe e alcoometria: as escolas ...

Pesquisadora-professora: Isso. Como a densidade da água é maior do que a do álcool, a água vai empurrar mais o aparelho para cima e é por isso que o 0 fica embaixo, porque a água tem zero de álcool. E se fosse o álcool puro, o aparelho iria afundar muito ou flutuar muito?

Amanda, seguida por vários alunos: Ia afundar.

Pesquisadora-professora: Exatamente. O álcool puro épouco denso e o aparetho penetra bastante nele, pois é empurrado pouco para cima. Por isso o 100 fica em cima na escala. E se fosse a cachaça?

Erivaldo, seguido por vários alunos: Fica no meio.

Pesquisadora-professora: Isso. Fica um valor intermediário, porque o teor de álcool da cachaça varia de 38 a $48^{\circ}$ G.L. Se fosse uma cachaça com $48{ }^{\circ} \mathrm{G}$.L. ficaria quase no meio, pois essa cachaça tem $48 \%$ de álcool e $52 \%$ de água.

Erivaldo, seguido por vários alunos: Se fosse com 38, ficaria menos afundado.

Ao explicarmos o conceito de densidade, os alunos foram orientados a dividir as massas de álcool (480 g), cachaça (540 g) e água (600 g) pelo volume dos líquidos (600 mL), e obtiveram o valor aproximado da densidade das três substâncias: $0,8 \mathrm{~g} / \mathrm{cm}^{3}, 0,9 \mathrm{~g} / \mathrm{cm}^{3} \mathrm{e} 1 \mathrm{~g} /$ $\mathrm{cm}^{3}$, respectivamente. Em seguida, correlacionamos o conceito de densidade à força exercida pelo líquido para cima, o empuxo, que contrabalança a força exercida pelo aparelho para baixo, sendo que os alunos passaram a reinterpretar o funcionamento dos aparelhos.

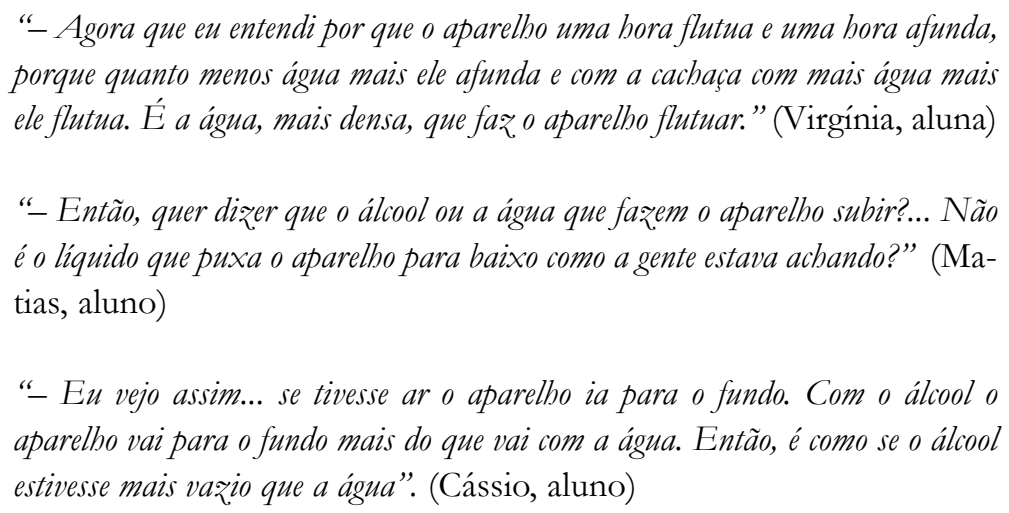

\section{Saberes locais... a mistura da cachaça}

Ao longo das atividades, constatamos que os produtores e os alunos tinham experiências cotidianas relacionadas à diferença de densidade entre a água e o álcool. Vários alunos que trabalham em alambique comentaram que o tonel de $100 \mathrm{~L}$, quando cheio de água, é "mais pesado" do que quando cheio de cachaça. Quando expusemos o registro fílmico da visita ao engenho de D. Rosa, a aluna Inês perguntou intrigada: "por que naquela hora D. Rosa pegou um pedaço de cano e ficou batendo dentro da vasilha?". Como não percebemos esse gesto descrito pela 
Almeida, R. O.

aluna nem no dia da visita nem no vídeo, o professor Evanilson esclareceu: "na bora que ela ficon batendo... pá, pá, pá, pá, pá..."’3.

A aluna Amanda não só tinha percebido o gesto, como sabia seu significado: "ela bateu pra misturá toda a cachaça e depois pegá e vê o ajofre" "14. Esse seu comentário ajudou-nos a compreender que D. Rosa, mesmo nunca tendo estudado densidade, sabia! que a cachaça fraca, que tem mais água, vai para o fundo quando cai, enquanto a cachaça forte, que tem mais álcool, desloca-se para cima, sendo que aquele gesto era para homogeneizar o grau alcoólico de toda a cachaça do galão antes de retirar a amostra para o teste.

Em todas as demais escolas, analisamos o significado daquele gesto de D. Rosa no sentido de fazer circular os saberes cotidianos e científicos relacionados ao fenômeno. A aluna Virgínia contou para os colegas que seu pai também faz essa mistura da cachaça: "ele pega o galão e sacode". Os alunos concluíram entusiasmados que o produtor poderia enganar o comprador, caso não fizesse essa mistura da cachaça antes da retirada da amostra para a medida com o alcoômetro. Arilson, filho de D. Rosa, confirmou a mistura da cachaça por sua mãe, contando que faz o mesmo gesto ${ }^{15}$, quando ajuda na produção, mas que nunca tinha refletido sobre o seu significado.

\section{Densidade e temperatura}

Depois de todo o esforço para que os alunos entendessem a variação da densidade das substâncias em função da temperatura, através da realização dos experimentos e da observação do comportamento do mercúrio no termômetro, que "sobe porque esquenta e fica menos denso", "o calor torna o mercúrio menos denso", "a mão esquentou o mercúrio e ele dilatou e subiu", constatamos que certas experiências cotidianas dos alunos poderiam ter sido logo acionadas para

\footnotetext{
${ }^{13}$ Esse episódio indica que, de fato, como enfatiza Rosenfeld (2000), é necessário rompermos com as bases sobre as quais construímos nosso sistema cognitivo e simbólico, quando nos propomos a realizar a análise do registro fílmico das atividades cotidianas, pois ela exige uma modificação de nossos hábitos sensoriais, ao mesmo tempo em que permite que vejamos coisas que não poderíamos ver na observação direta.

${ }^{14}$ Ao tratar da história e do valor educativo do aprender-fazendo, Rugiu (1998, prefácio) põe em questão a concepção oposta à pedagogia artesã, que surge a partir do século XVII, segundo a qual "a verdadeira educação e a verdadeira instrução são somente aquelas que se assimilam através do exercício e do aprendizado intelectual, estudando-se os livros e escutando-se a voz do mestre, nas carteiras das escolas ou da universidade, e não sujando as mãos, por assim dizer, produzindo objetos materiais [...]”. Para esse autor, na ideologia pedagógica artesã, o exercício mental era incorporado ao exercício prático ou aos objetos produzidos, de forma que a ideia de preeminência cultural de símbolos abstratos ou de formas intelectuais universais permanecia ainda distante. O comentário dessa aluna evidencia que, mesmo atualmente, em que há a valorização dos conteúdos didáticos formais, ainda é possível perceber uma autêntica, embora praticamente imperceptível, atividade didática e formativa nas unidades de produção artesanais.

${ }^{15}$ Destacamos o valor do registro fílmico na pesquisa antropológica e educacional, como suporte persistente, contínuo e que pode ser reexaminado a qualquer momento. Através da observação diferida, Arilson e seus colegas reviram o gesto de $\mathrm{D}$. Rosa e, por meio de nossa mediação pedagógica, puderam ressignificá-lo. O gesto fugaz e aparentemente banal de D. Rosa, apreendido pelo filme, passou-nos despercebido até mesmo na observação diferida, tendo sido necessária a mediação pedagógica dos alunos para que pudéssemos percebê-lo (FRANCE, 1998; 2000; ROSENFELD, 2000).
} 
Ajofe e alcoometria: as escolas ...

que eles dessem sentido ao conteúdo de aprendizagem e, ao mesmo tempo, a essas experiências, como se evidenciou no seguinte episódio:

Pesquisadora-professora: Na visita ao engenho de Luís eu vou pedir que vocês façam uma observação. Não tem a caixa d'água onde fica a serpentina, por dentro da qual passa o vapor da cachaşa para ser esfriado? Então, vocês vão colocar a mão dentro da caixa, mais na superfície, e depois vão colocar a mão mais embaixo. Vários alunos: Em cima é quente e embaixo é fria!

Pesquisadora-professora: Por que em cima fica quente e embaixo fica fria? Márcio: Porque a seripitina do alambique fica mais em cima.

Pesquisadora-professora: $O$ calor do vapor começa a passar para a água na parte de cima, é verdade... mas não é só por isso não...

Luciene: Também porque bota fogo embaixo na fornalha...

Pesquisadora-professora: Mas na caixa d'água não bota fogo não... bota é no alambique. O que nós vimos hoje?...

Vários alunos: A água fria fica no fundo...

Pesquisadora-professora: A água fria é mais densa e por isso ela fica no fundo.

Luiz Cláudio: No rio, a água que fica na parte de baixo é mais fria do que a de cima! $^{16}$

Vários alunos relembraram a observação feita nas visitas que realizamos aos engenhos e suas experiências: "D. Rosa deixa entrar uma água fria por um cano por baixo para empurrar a água quente que fica em cima pra fora... agora entendi porque a água tem que circular!", "na caixa a água embaixo é mais fria!", "no rio Agua Suja a água embaixo fica mais fria... gelada", "quando a gente entra num rio a água por cima é bem quentinha e fica gelada no fundo", "a água fria, do fundo, é mais pesada e a água quente, da superfície, é mais leve".

Vários alunos fizeram predições corretas sobre a variação da massa de garrafas, com o mesmo volume, em função da temperatura das substâncias: "a garrafa com garapa quente ou com cachaça quente vai ter menor massa". Os alunos constataram, de maneira experimental, o aumento do volume da cachaça, inicialmente gelada, ao ser colocada em banho-maria, interpretando-o: "rendeu mais, pois as moléculas dilataram", sendo que explicamos que ocorreu o afastamento das moléculas. A aluna que trabalha na inspeção da limpeza da cachaça engarrafada comentou: "agora en entendi! O calor da lâmpada dilata a cachaça e aumenta o volume". Ao compararem as massas de duas garrafas de $600 \mathrm{~mL}$, uma com cachaça fria e a outra com cachaça quente, verificaram que a primeira apresentava, de fato, alguns gramas a mais que a segunda.

\footnotetext{
${ }^{16}$ Acionar as experiências prévias não é o bastante para que os alunos construam os conceitos científicos, pois os alunos elaboram outras explicações igualmente coerentes. Assim, se para Márcio a água da superfície fica quente "porque a seripitina do alambique fica mais em cima", outros alunos apresentaram argumentos como "o vapor entra na serpentina por cima", "a água do rio esquenta de cima pra baixo... o sol bate por cima!". Outras evidências foram acionadas para que os alunos fossem convencidos de que a disposição do líquido quente na superfície era devido à variação da densidade das substâncias em função da temperatura, como o movimento de convecção da água, em que a água quente vai para cima, mesmo sendo aquecida de baixo para cima.
} 
Almeida, R. O.

Uma aluna fez um comentário reflexivo sobre a forma como vivencia o cotidiano:

"- Então, quer dizer que a água quente é mais leve do que a fria?...E a garapa e a cachaça também!... Eu não sabia disso não!... Sabe, antes dessas aulas tinha umas coisas assim que a gente via, mas não entendia! Eu sempre fazia cachaça, mas não sabia nem como que... se alguém me perguntasse essas coisas eu não sabia explicar. Alguém faz uma pergunta e a gente nem sabe como responder!” (Elisabete, aluna)

\section{Os quadros de correção: por que somar ou subtrair?}

A abordagem da variação da densidade em função da temperatura resultou no entendimento, pelos alunos do Ensino Médio, de que "o calor faz a garapa e a cachaça ficá mais leves e o frio faz ficá mais pesadas, empurrando os aparelhos de forma diferente para cima", "a garapa vai esfriando e ficando mais densa, empurrando mais o aparelho pra cima, por isso que vai aumentando o valor lido", o que facilitou a compreensão, pelos alunos, de que o sacarímetro e o alcoômetro teriam de ser usados de forma associada a um termômetro e aos quadros de correção, porque "o valor lido nos aparelhos não é igual ao real".

Em todas as turmas, após a explicação de que os aparelhos estão aferidos em $20{ }^{\circ} \mathrm{C}$, confirmada pela leitura desse valor neles inscrito, e de comentários como o de que "o valor lido no aparelho só é real se a garapa ou a cachaça estiverem a $20^{\circ} \mathrm{C}$, mas que seria complicado ficar esquentando e esfriando os líquidos antes de efetuar as leituras", os alunos realizaram medidas do teor de açúcares de diversas amostras de garapa e do grau alcoólico de diversas amostras de cachaça, bem como de suas temperaturas, consultando, com nossa mediação, o quadro de correção para verificar os valores que teriam de ser subtraídos ou adicionados aos valores lidos. Diante do comentário de que os poucos produtores da região que têm os aparelhos não costumam fazer a correção, e que ela é importante na relação comercial para que não tenham prejuízo, Amanda respondeu, ao questionarmos para quem seria vantagem efetuar a medida, não acompanhada da correção, com a cachaça quente: "se a cachaça quente parece mais forte, é melhó pro produtô medí enquanto ela tá quente. E pro compradô, quando ela tá fria!... Se fizé correção, ninguém fica prejudicado".

Apesar de seu envolvimento nas aulas, Amanda continuou sem entender por que as operações de adicionar e subtrair eram invertidas: "eu tô gostando do trabalho, só que esse negócio de adicioná e subtraí eu num tô intendendo não!". Como ela manifestou ter entendido bem que a necessidade de somar ou de subtrair é porque a temperatura afeta a densidade da garapa e da cachaça, afirmando "isso eu intendi! É porque eu sô muito ruim de Física", suspeitamos que ela, e talvez outros alunos, não tivessem entendido que a inversão das operações nos quadros de correção tinha relação com a inversão das escalas nos aparelhos, pelo fato de que a garapa é mais densa que a água e a cachaça menos densa que a água.

Para favorecer a compreensão, por Amanda e por seus colegas, das operações inversas no sacarímetro e no alcoômetro, comparamos a disposição das escalas dos aparelhos, construindo coletivamente um esquema no quadro, o qual ajudou na compreensão de que a subtração e a soma são formas de compensar a variação da densidade das substâncias em função da temperatura. Amanda, animada e mostrando os aparelhos, disse: "agora eu entendi! Agora ficou claro! É porque nos aparelhos também é invertido! A gente já viu isso antes!". Quando perguntamos "mas 
Ajofe e alcoometria: as escolas ...

por que as escalas dos aparelhos são invertidas?", ela explicou com desenvoltura: "quanto mais doce a garapa ela fica mais densa e o aparelho flutua mais, e épor isso que os número grande tem que ficá embaixo. Já quanto mais forte a cachaça, ela fica menos densa, porque tem mais álcool, e o aparelho afunda mais. Então os número grande tem que ficá em cima". Raciocínios refinados como o de Amanda são contraevidências contundentes ao discurso estigmatizante em relação às possibilidades de abstração e de resposta aos desafios cognitivos pelos supostamente rústicos alunos do campo.

Ao discutirmos a possibilidade de popularização do uso dos aparelhos, chegamos à conclusão de que os poucos produtores da região que têm sacarímetros e alcoômetros, em geral, desconhecem os princípios físicos de seu funcionamento e não fazem a correção. $O$ professor Henrique manifestou preocupação com a exigência de mais um aparelho: "muitos têm e não usam e quem usa não corrige... mas, sendo assim, tem que ter um termômetro, né??". Para a maioria dos alunos, os produtores teriam condição de aprender a usar os aparelhos, sendo que Amanda afirmou enfática: "aprendem! Tendo uma orientação". Para o professor Henrique, "tendo a prática, aprendem".

Um aspecto relevante, ao se discutirem as relações entre ciência, tecnologia e sociedade, é a frequente invenção de novos aparelhos, cuja concepção e difusão envolvem custos que nem sempre resultam nos benefícios sociais correspondentes, como o alcoômetro com termômetro e escala acoplados, que permitem efetuar diretamente a compensação das medidas, dispensando o uso do quadro de correção ${ }^{17}$. Os alunos constataram experimentalmente que os aparelhos com termômetro e escala de correção acoplados fornecem o mesmo resultado que o método convencional com emprego do quadro de correção.

Arilson, filho de D. Rosa, manifestou preocupação com os produtores da cachaça comum e interesse pela difusão entre eles do uso dos aparelhos e do procedimento de correção, afirmando que "a gente tem que confiá no que o atravessador diz e quem ganha é o atravessador! Nós não ganha quase nada não!'” Para ele é muito fácil aprender a usar os aparelhos, sendo mais fácil até mesmo do que "saber se a cachaşa tá forte pelo cheiro ou pelas bolhas, que exige muito mais experiência".

No Ensino Fundamental, apesar de os alunos terem tido certa dificuldade para entender o raciocínio de compensação envolvido no uso do termômetro e do quadro de correção, estas dificuldades não foram maiores do que entre os alunos do Ensino Médio. Quando perguntei por que é importante fazer a correção, Cassiano explicou: "não dá pra ficar esfriando e esquentando a cachaça pra ela ficar a exatamente 20 graus toda vez. que vai faz̧er a medida!". Também manifestaram ter compreendido que a necessidade de uso do aparelho decorre da variação da densidade da cachaça em função da temperatura:

\footnotetext{
${ }^{17}$ No final do século XVIII, foi introduzida, nos alcoômetros, a escala Cartier (1771), sendo substituída, no meio científico, pela escala Gay-Lussac no início do século XIX (1824), época em que foi inventado o sacarímetro, por Brix (1836). Porém, em Abaíra, esses aparelhos são pouco usados e ainda se faz referência à antiga escala Cartier. Segundo Pires e Afonso (2006), o densímetro com termômetro e escala de correção acoplados é bem antigo, sendo que, em 1885, já eram fabricados alcoômetros associados a termômetros e, em 1892, já eram produzidos sacarímetros acoplados a termômetros. Segundo estes autores, "a praticidade do uso, o baixo custo e a leitura simultânea de dois parâmetros de grande importância prática responderam pela ampla aceitação do instrumento no mercado consumidor, [...] particularmente nas indústrias fermentativas" (PIRES; AFONSO, 2006, p. 1398). Essa ideia universalizante contradiz a experiência histórica, pelo menos no setor de produção artesanal de cachaça.
} 
Almeida, R. O.

Pesquisadora-professora: Vimos que o gran alcoólico da cachaça "Abaira" é sempre $42{ }^{\circ} \mathrm{G}$.L., estando escrito aqui no rótulo. Se uma amostra dela estivesse quente, o aparelho iria marcar 42 ?

Vários alunos: Não!

Pesquisadora-professora: $O$ aparelho vai descer mais on descer menos?

Ivan: Descer mais.

Pesquisadora-professora: Por quê?

Érica: Porque a cachaça quente é mais leve e o aparelho afunda mais.

Pesquisadora-professora: Isso, o aparelho vai afundar mais e vai dar um valor maior que $42{ }^{\circ} \mathrm{G}$.L. Por exemplo, a temperatura poderia estar a $25^{\circ} \mathrm{C}$ e o teor alcoólico poderia estar a $44^{\circ} \mathrm{G}$.L. Quando a gente cruza $44^{\circ} \mathrm{G}$.L. com $25^{\circ} \mathrm{C}$, o que o quadro recomenda?

Vários alunos: Subtrair 2.

Pesquisadora-professora: Vejam que $44^{\circ}$ G.L. menos 2 dá $42^{\circ}$ G.L., que é grau alcoólico real da cachaça "Abaira". E na cachaça fria, o que iria acontecer com o aparelho?

Vários alunos: Subir mais, porque a cachaça fria é mais pesada.

Pesquisadora-professora: Isso. Como a cachaça fria é mais densa, ela vai empurrar o aparelho pra cima e ele vai flutuar mais, dando um valor menor que $42{ }^{\circ} \mathrm{G}$.L. A temperatura poderia, por exemplo, estar a $15^{\circ} \mathrm{C}$ e a medida teria sido $40{ }^{\circ} \mathrm{G}$.L, Quando a gente cruza $40^{\circ} \mathrm{G}$.L. com $15{ }^{\circ} \mathrm{C}$, o que o quadro recomenda?

Vários alunos: Adicionar 2.

Pesquisadora-professora: Vejam que $40^{\circ}$ G.L. mais 2 dá também $42{ }^{\circ} G$.L, que é grau alcoólico real da cachaça "Abaíra".

Érico: Então, a cachaşa "Abaira" tem sempre 42! O aparelho pode marcar diferente, mas é por causa da temperatura que faz a cachaça ficar mais leve ou mais pesada.

Pesquisadora-professora: Isso. A cachaça vai ficar mais densa ou menos densa com a variação da temperatura.

Os alunos consideraram importante que os produtores soubessem não apenas manipular os aparelhos, mas também entendessem o seu funcionamento para darem sentido ao seu dia-a-dia. Quando perguntamos a Rosimeire se ela achava que seu pai teria condição de aprender, com receio de que ela poderia achar que seria difícil, tanto eu quanto o professor Henrique, que vê com desconfiança a possibilidade de os produtores incorporarem as inovações, tivemos uma grande surpresa com a resposta: "acho que sim. Acho que, se ele comprá o aparelho, sożinho ele não vai entendê, agora, se ele ouvi uma explicação dessa, ele é capaz de entendê, porque de matemática ele entende bastante!". Outros alunos concordaram: "aprendia! Se a gente tá entendendo, por que ele não ia entendê?". 
Ajofe e alcoometria: as escolas ...

\section{Considerações finais}

O envolvimento em situações de aprendizagem interativas, ancoradas na experiência cultural, oportunizou a professores e alunos atribuírem novos valores à prática local de produção de cachaça e à própria escola, evidenciando que a perspectiva de circularidade entre as culturas (GINZBURG, 1987; TURA, 2002) constitui um importante referencial teórico-metodológico no campo educacional. A partir de uma concepção de que modernizar é carregar junto o passado, e não destruí-lo, professores e alunos puderam lançar um novo olhar à aparente rotina do cotidiano, deparando-se com desafios cognitivos que exigiram operações mentais complexas e a construção de conceitos científicos, de relevância universal, cuja apropriação demandou a intervenção educativa sistemática no sentido de se estabelecer relações entre as ações discursivas nas salas de aula e o contexto social mais amplo (CANDELA, 1998).

A partir da consideração dos desdobramentos sociais de nossa intervenção e por considerarmos que a abordagem de temas polêmicos deve ser contemplada no projeto político-pedagógico da escola, com o envolvimento de todos os professores, para que sejam tratados em toda a sua complexidade, decidimos que o foco do posicionamento dos alunos se concentraria na discussão de questões em torno do tema: "ajofe e alcoometria: podem viver juntos?", comparando as vantagens e desvantagens dos procedimentos técnicos envolvidos nas duas modalidades de produção de cachaça, visando superar um enfoque meramente opinativo e, assim, propiciar um ambiente favorável ao desenvolvimento da competência argumentativa, necessária à democracia participativa na busca de decisões partilhadas em torno das estratégias locais de identidade.

Ao final desse processo formativo, em que tomamos como desafio realizar intervenções educativas envolvendo a negociação de significados e a circulação de saberes - tendo a cultura local como referência, com vistas a analisar a sua influência nas disposições cognitivas dos alunos para a aprendizagem de conceitos científicos e para ressignificar suas experiências -, percebemos que os alunos passaram a dar novos sentidos a antigas práticas locais ${ }^{18}$, e que os professores envolvidos passaram a atribuir novos significados aos processos de aprendizagem, percebendo a importância da ancoragem social dos conteúdos escolares.

${ }^{18}$ A avaliação, numa perspectiva multicultural, deve buscar compreender se o diálogo entre os universos culturais dos alunos e os padrões culturais diversos apresentados pelo professor está sendo bem-sucedido (CANEN, 2002). Nesse sentido, a capacidade de (re)interpretação de situações cotidianas ao longo das aulas foi tomada como parâmetro de avaliação do processo de aprendizagem. 
Almeida, R. O.

\section{Referências}

ALMEIDA, M. C. D. P. e. Ensaio sobre o fabrico do açúcar. Salvador: FIEB, 2002. (Documentos Históricos, 1).

ALMEIDA, M. J. P. M. de. Discursos da ciência e da escola: ideologia e leituras possíveis. Campinas, SP: Mercado das Letras, 2004.

ALMEIDA, R. O. Ajofe e alcoometria: poderão viver juntos? As escolas diante das mudanças socioculturais ligadas à produção de cachaça artesanal na microrregião de Abaíra - BA. 2008. 347 f. Tese (Doutorado em Educação) - Faculdade de Educação, Universidade Estadual de Campinas, Campinas, 2008.

AULER, D. Enfoque ciência-tecnologia-sociedade: pressupostos para o contexto brasileiro. Ciência \& Ensino, Campinas, v. 1, nov. 2007. (número especial). Disponível em: <http:// www.ige.unicamp.br/ojs/index.php/cienciaeensino/article/view/147/109>. Acesso em: 22 jun. 2008.

AZEVEDO, J. C. de. Reconversão cultural da escola: mercoescola e escola cidadã. Porto Alegre: Sulina, 2007.

AZIBEIRO, N. E. Educação intercultural e complexidade: desafios emergentes a partir das relações em comunidades populares. In: FLEURY, R. M. (Org.). Educação intercultural: mediações necessárias. Rio de Janeiro: DP\&A, 2003. p. 85-107.

BRANDÃO, C. R. Em campo aberto: escritos sobre a educação e a cultura popular. São Paulo: Cortez, 1995.

BRASIL. Instrução normativa $n^{\circ} 13$, de 29 de junho de 2005. Aprova o regulamento técnico para fixação dos padrões de identidade e qualidade para aguardente de cana e para cachaça. Diário Oficial da União, Brasília, 30 jun. 2005. Seção 1. p. 3. Disponível em: $<$ http://extranet.agricultura.gov.br/sislegis-consulta/consultarLegislacao.do?operacao= visualizar\&id=12386> . Acesso em: 22 maio 2007.

CANCLINI, N. G. Culturas híbridas: estratégias para entrar e sair da modernidade. 3. ed. São Paulo: EDUSP, 2000.

CANDELA, A. A construção discursiva de contextos argumentativos no ensino de Ciências. In: COLL, C.; EDWARDS, D. Ensino, aprendizagem e discurso na sala de aula: aproximações ao estudo do discurso educacional. Porto Alegre: Artmed, 1998. p. 143-169.

CANEN, A. Sentidos e dilemas do multiculturalismo: desafios curriculares para o novo milênio. In: LOPES, A. C.; MACEDO, E. (Org.). Currículo: debates contemporâneos. São Paulo: Cortez, 2002. p. 174-195.

CERTEAU, M. de. A cultura no plural. Campinas, SP: Papirus, 1995.

ELIAS, N. O processo civilizador: uma história dos costumes. Rio de Janeiro: Jorge Zahar, 1994 
Ajofe e alcoometria: as escolas ...

FERREIRA, A. B de H. Novo Aurélio século XXI: o dicionário da língua portuguesa. Rio de Janeiro: Nova Fronteira, 1999.

FRANCE, C. de. Cinema e antropologia. Campinas: Editora da Unicamp, 1998.

Antropologia fílmica: uma gênese difícil, mas promissora. In: . (Org.). Do

filme etnográfico à antropologia fílmica. Campinas: Editora da Unicamp, 2000. p. 17-42.

GINZBURG, C. O queijo e os vermes: o cotidiano e as ideias de um moleiro perseguido pela inquisição. São Paulo: Companhia das Letras, 1987.

GIROUX, H.; SIMON, R. Cultura popular e pedagogia crítica: a vida cotidiana como base para o conhecimento curricular. In: MOREIRA, A. F. B.; SILVA, T. T. da (Org.). Currículo, cultura e sociedade. São Paulo: Cortez, 1994. p. 93-124.

HALL, S. A identidade cultural na pós-modernidade. 10. ed. Rio de Janeiro: DP\&A, 2005.

Quem precisa da identidade? In: SILVA, T. T. da. (Org.). Identidade e diferença: a perspectiva dos estudos culturais. 2. ed. Petrópolis: Vozes, 2000. p. 103-133.

INFÂNCIA perdida. [S. 1.]: Rede Globo de Televisão, 2 abr. 2006. Reportagem de televisão. Disponível em: <http:// fantastico. globo.com/Jornalismo/FANT/0,„MUL695554-

15605,00.html>. Acesso em: 6 maio 2006.

MACEDO, E. Ciência, tecnologia e desenvolvimento: uma visão cultural do currículo de ciências. In: LOPES, A. C.; MACEDO, E. (Org.). Currículo de ciências em debate. Campinas, SP: Papirus, 2004. p. 119-152.

MOREIRA, A. F. B. Propostas curriculares alternativas: limites e avanços. Educação \& Sociedade, Campinas, v. 21, n. 73, p. 109-138, dez. 2000. Disponível em: <http:// www.scielo.br/pdf/es/v21n73/ 4210.pdf>. Acesso em: 15 maio 2006.

MORTIMER, E. F.; SCOTT, P. Atividade discursiva nas salas de aula de ciências: uma ferramenta sociocultural para analisar e planejar o ensino. Investigações em Ensino de Ciências, Porto Alegre, v. 7, n. 3, p. 283-306, 2002. Disponível em: <http:// www.if.ufrgs.br/ienci/artigos/Artigo_ID94/v7_n3_a2002. pdf>. Acesso em: 12 jan. 2006.

NELSON, C.; TREICHLER, P. A.; GROSSBERG, L. Estudos culturais: uma introdução. In: SILVA, T. T. da (Org.). Alienígenas na sala de aula: uma introdução aos estudos culturais em educação. 3. ed. Petrópolis: Vozes, 2001. p. 7-38

PIRES, D. P. L.; AFONSO, J. C. Do termoscópio ao termômetro digital: quatro séculos de termometria. Química Nova, São Paulo, v. 29, n. 6, p. 1393-1400, 2006. Disponível em: $<$ http:/ /quimicanova.sbq.org.br/ qn/qnol/ 2006/vol29n6/40-AG05250.pdf>. Acesso em: 12 ago. 2006.

ROSENFELD, J. Filmar: uma reconversão do olhar. FRANCE, C. de (Org.). Do filme etnográfico à antropologia fílmica. Campinas: Editora da Unicamp, 2000. p. 43-53. 
Almeida, R. O.

RUGIU, A. S. Nostalgia do mestre artesão. Campinas, SP: Autores Associados, 1998.

SILVA, T. T. da. A produção social da identidade e da diferença. In: (Org.).

Identidade e diferença: a perspectiva dos estudos culturais. 2. ed. Petrópolis: Vozes, 2000.

p. 73-102.

TURA, M. de L. R. Conhecimentos escolares e a circularidade entre culturas. In: LOPES, A. C.; MACEDO, E. (Org.). Currículo: debates contemporâneos. São Paulo: Cortez, 2002. p. 150-173.

VARGENS, J. B. M. Léxico português de origem árabe: subsídios para os estudos de filologia. Rio Bonito, RJ: Almádena, 2007.

VYGOTSKY, L. S. A formação social da mente. 3. ed. São Paulo: Martins Fontes, 1989.

Artigo recebido em 28/03/2011. Aceito em 31/08/2011. 